\title{
B-Ephrin Reverse Signaling Is Required for NMDA-Independent Long-Term Potentiation of Mossy Fibers in the Hippocampus
}

\author{
John N. Armstrong, ${ }^{1}$ Michael J. Saganich, ${ }^{1}$ Nan-Jie Xu, ${ }^{2}$ Mark Henkemeyer, ${ }^{2}$ Stephen F. Heinemann, ${ }^{1}$ and \\ Anis Contractor ${ }^{3}$ \\ ${ }^{1}$ Molecular Neurobiology Laboratory, The Salk Institute, La Jolla, California 93037, ${ }^{2}$ Center for Developmental Biology and Kent Waldrep Foundation \\ Center for Basic Neuroscience Research on Nerve Growth and Regeneration, University of Texas Southwestern Medical Center, Dallas, Texas 75235, and \\ ${ }^{3}$ Department of Physiology and Northwestern University Institute for Neuroscience, Northwestern University Feinberg School of Medicine, Chicago, Illinois \\ 60611
}

The mossy fiber to CA3 pyramidal neuron synapse in the hippocampus displays an atypical form of NMDA receptor-independent long-term potentiation (LTP). Plasticity at this synapse is expressed in the presynaptic terminal as an elevated probability of neurotransmitter release. However, evidence indicates that postsynaptic mechanisms and trans-synaptic signaling through an association between postsynaptic EphB receptors and presynaptic B-ephrins are necessary for the induction of LTP. Here we show that ephrin-B3 protein is highly expressed in mossy fiber axons and terminals. There are specific deficits in mossy fiber LTP in mice in which the cytoplasmic $\mathrm{C}$-terminal signaling domain of the ephrin-B3 protein is replaced with $\beta$-galactosidase. These deficits are not observed in ephrin-B3 null mutant mice because of functional redundancy by virtue of other B-ephrins. These results indicate that B-ephrin reverse signaling into the presynaptic mossy fiber bouton is required for the induction of NMDA receptor-independent LTP at this synapse.

Key words: long-term potentiation; mossy fiber; hippocampus; ephrin; pyramidal neuron; presynaptic signaling

\section{Introduction}

Long-term potentiation (LTP) is a widely studied form of synaptic plasticity that is important for development and experiencedependent modification of behavior. Investigations of the molecular mechanisms underlying this phenomenon have revealed that LTP is not a homogenous characteristic of synapses but rather is a group of processes with diverse underlying mechanisms (Malenka and Bear, 2004). Synaptic plasticity has been most extensively studied in the hippocampus because of its central role in learning, and several forms of LTP have been described at hippocampal synapses. LTP at the mossy fiber to pyramidal cell synapse in the CA3 region of the hippocampus is independent of the activation of NMDA receptor (Harris and Cotman, 1986), and expression of mossy fiber LTP is associated with an increase in the probability of neurotransmitter release and is, therefore, dependent on presynaptic mechanisms (Weisskopf and Nicoll, 1995). Direct support for the role of presynaptic mechanisms comes from studies in which ablation of the active zone protein

Received 0ct. 11, 2005; revised Feb. 9, 2006; accepted Feb. 14, 2006.

This work was supported by grants from the National Institutes of Health (NIH)/National Institute of Neurological Disorders and Stroke (S.F.H., A.C.), NIH/National Institute of Mental Health (M.H., A.C.), and National Alliance for Research on Schizophrenia and Depression (J.N.A.). We thank Kacee Jones, Stephanie Bennett, and Antonine Kaise for genotyping and mouse husbandary of animals used in the study. We also thank Geoffrey Swanson for critically reviewing this manuscript.

Correspondence should be addressed to Anis Contractor, Department of Physiology, Northwestern University Feinberg School of Medicine, 303 East Chicago Avenue, Chicago, IL 60611. E-mail: a-contractor@northwestern.edu. DOI:10.1523/JNEUROSCI.4338-05.2006

Copyright $\odot 2006$ Society for Neuroscience $\quad 0270-6474 / 06 / 263474-08 \$ 15.00 / 0$
Rab3-interacting molecule 1 (RIM1) (Castillo et al., 2002) or the synaptic vesicle-associated protein Rab3A (Castillo et al., 1997) resulted in impairment of mossy fiber LTP. Despite this firmly established presynaptic localization for the expression of mossy fiber LTP, a consensus for postsynaptic involvement has not been established (Yeckel et al., 1999; Mellor and Nicoll, 2001). A model proposing postsynaptic mechanisms in mossy fiber LTP would require a signal to transfer information from the postsynaptic neuron to the presynaptic terminal in an activity-dependent manner for the long-lasting increase in neurotransmitter release to occur. In a previous study, we provided evidence that a transsynaptic EphB receptor to B-ephrin interaction fulfilled this retrograde signaling role at mossy fiber synapses (Contractor et al., 2002). EphB receptors and their cognate ligand partners, the B-ephrins, are synaptically localized membrane-bound signaling molecules critical to plasticity in both the developing and adult CNS (Kullander and Klein, 2002; Murai and Pasquale, 2002). Intercellular interaction between these molecules triggers bidirectional signaling through their intracellular cytoplasmic signaling domains (Cowan and Henkemeyer, 2002). Disrupting Eph receptor association with scaffolding proteins in the postsynaptic cell or application of reagents that block extracellular EphB receptor interactions with B-ephrins impairs the induction and expression of mossy fiber LTP (Contractor et al., 2002). To further investigate the role of B-ephrin signaling in mossy fiber synaptic plasticity and to identify the specific molecules that may contribute to activity-dependent signaling, in this study, we ana- 
lyzed mossy fiber synaptic transmission in two strains of genetically targeted ephrin-B3 mutant mice. mRNAs for all three $\mathrm{B}$-ephrins are expressed in the dentate granule cells, but ephrin-B3 is the most abundant (Grunwald et al., 2001; Liebl et al., 2003). In mice in which the cytoplasmic signaling domain of ephrin-B3 is replaced by a bacterial lac Z cassette to form a membrane-bound ephrin-B3- $\beta$-galactosidase fusion protein, we find a specific impairment in LTP at mossy fiber synapses. In contrast, in mice in which the ephrin-B3 locus has been targeted to produce a hypomorphic null mutation, mossy fiber LTP is not affected. We propose that a reverse signal into mossy fiber boutons mediated by B-ephrins is required for mossy fiber LTP, and disruption of this signaling pathway by a dominant-negative ephrin-B3- $\beta$-galactosidase fusion protein leads to a disruption in this form of synaptic plasticity.

\section{Materials and Methods}

Electrophysiology. Horizontal hippocampal slices $(350 \mu \mathrm{m})$ were prepared from postnatal day 14 (P14) to P28 juvenile mice. All experiments were performed with the experimenter blind to the genotype. Both ephrin-B3 ${ }^{\text {neo/neo }}$ and ephrin-B $3^{\text {lacZ/lacZ }}$ strains were in an isogenic CD-1 background. Tail biopsies were taken from all mice used in electrophysiology experiments, and genotype was determined using PCR. Animals were anesthetized with isoflurane and decapitated. The brain was removed under ice-cold oxygenated sucrose-slicing artificial CSF (ACSF) containing the following (in mM): $85 \mathrm{NaCl}, 2.5 \mathrm{KCl}, 1.25 \mathrm{NaH}_{2} \mathrm{PO}_{4}, 25$ $\mathrm{NaHCO}_{3}, 25$ glucose, 75 sucrose, $0.5 \mathrm{CaCl}_{2}$, and $4 \mathrm{MgCl}_{2}$ (equilibrated with $95 \% \mathrm{O}_{2} / 5 \% \mathrm{CO}_{2}$ ). Slices were incubated at $28^{\circ} \mathrm{C}$ for $30 \mathrm{~min}$, followed by exchange of the sucrose ACSF for an oxygenated sodium ACSF solution containing the following (in $\mathrm{mm}$ ): $125 \mathrm{NaCl}, 2.4 \mathrm{KCl}, 1.2$ $\mathrm{NaH}_{2} \mathrm{PO}_{4}, 25 \mathrm{NaHCO}_{3}, 25$ glucose, $1 \mathrm{CaCl}_{2}$, and $2 \mathrm{MgCl}_{2}$. Individual slices were transferred to a recording chamber and visualized under Nomarski optics. In the recording chamber, slices were continuously perfused with oxygenated sodium ACSF containing $2 \mathrm{mM} \mathrm{CaCl}_{2}$ and $1 \mathrm{~mm}$ $\mathrm{MgCl}_{2}$. Glass electrodes were fabricated from borosilicate glass and had resistances of 3-4 $\mathrm{M} \Omega$ when filled with $\mathrm{CsF}$ internal solution containing the following (in mM): $95 \mathrm{CsF}, 25 \mathrm{CsCl}, 10 \mathrm{Cs}$-HEPES, $10 \mathrm{Cs}$-EGTA, $2 \mathrm{NaCl}, 2$ Mg-ATP, 10 QX-314 [N-(2,6-dimethylphenylcarbamoylmethyl)triethylammonium bromide, and 5 4-AP, pH adjusted to 7.3 with $\mathrm{CsOH}$. Whole-cell voltage-clamp recordings were made from visually identified pyramidal cells in the CA3 region using an Axopatch 200B or $700 \mathrm{~B}$ patch-clamp amplifier (Molecular Devices, Palo Alto, CA). Series resistance was continuously monitored using hyperpolarizing voltage steps generated by pClamp 9 software (Molecular Devices), and recordings were discarded if there was a $>15 \%$ change during the course of the experiment. AMPA/kainate-mediated mossy fiber EPSCs were isolated using the $\mathrm{GABA}_{\mathrm{A}}$ antagonists bicuculline $(10 \mu \mathrm{M})$ and picrotoxin $(50 \mu \mathrm{M})$ and the NMDA receptor antagonist D-APV $(50 \mu \mathrm{M})$. Mossy fiber synaptic currents were evoked using a monopolar glass electrode filled with oxygenated ACSF positioned in the stratum lucidum. Stimuli were controlled by pClamp 9 software and generated with an A310 Accupulser coupled to an A360 stimulation isolation unit (Warner Instruments, Hamden, CT). Data collection and analysis were performed with pClamp 9, Excel (Microsoft, Seattle, WA), and Origin (Microcal Software, Northampton, MA) software. Mossy fiber EPSCs were identified by a large paired-pulse facilitation, brief onset latencies, and rapid EPSC rise times (Contractor et al., 2001) and by the addition of the group II metabotropic glutamate receptor (mGluR) agonist DCG-IV $\left[\left(2 S, 2^{\prime} R, 3^{\prime} R\right)-2-\left(2^{\prime}, 3^{\prime}\right.\right.$-dicarboxycyclopropyl)glycine] (1 $\left.\mu \mathrm{M}\right)$, which selectively suppresses mossy fiber transmission (Kamiya et al., 1996). Most of the recordings in this study were performed at room temperature, but, to eliminate the possibility of temperature-mediated effects, we performed some of the LTP recordings shown in Figure 3 at elevated temperature $\left(30^{\circ} \mathrm{C}\right)$.

For extracellular field potential $400 \mu \mathrm{m}$ hippocampal slices were prepared as described above. Recordings were made with a glass electrode filled with extracellular solution and placed in the stratum radiatum of the CA1 region, and Schaffer collateral inputs were activated with a concentric bipolar electrode placed at the border of CA2 and CA1. Bicuculline, picrotoxin, and D-APV were excluded from the external solution, and CA1 LTP was induced using a theta burst stimulation comprising six trains given at $10 \mathrm{~s}$ intervals and consisting of five bursts of $100 \mathrm{~Hz}$ for 40 $\mathrm{ms}$ separated by $200 \mathrm{~ms}$. The initial slope of the field response during the control period was compared with the slope 30-40 min after induction. Wild-type (wt) littermates from null and lacZ mice showed equivalent amounts of CA1 LTP, and therefore data from both sets of wild-type animals were pooled in these experiments. Two sample comparisons were made using the paired Student's $t$ test, and nonparametric data were tested for significance using the Kolmogorov-Smirnov test.

Histochemistry and image analysis. For X-galactosidase (X-gal) staining, fresh $200 \mu \mathrm{m}$ sections were obtained from P13-P16 mice as for electrophysiological experiments and fixed for $15 \mathrm{~min}$ in $4 \%$ paraformaldehyde in $0.1 \mathrm{M}$ phosphate buffer and were incubated overnight in a solution containing $5 \mathrm{~mm}$ potassium ferricyanide, $5 \mathrm{~mm}$ potassium ferrocyanide, and $1 \mathrm{mg} / \mathrm{ml} \mathrm{X-galactosidase.} \mathrm{Sections} \mathrm{were} \mathrm{washed} \mathrm{and}$ mounted onto charged slides with FluorSave (Calbiochem, La Jolla, CA).

For immunohistochemistry, adult wild-type and mutant mice were anesthetized and perfused transcardially with $4 \%$ paraformaldehyde in $0.1 \mathrm{M}$ phosphate buffer, $\mathrm{pH}$ 7.4. Brains were removed and sectioned in the coronal plane $(50 \mu \mathrm{m})$ on a vibrating microtome and processed for immunocytochemistry using standard procedures (Sloviter et al., 1996). Antibody incubations were performed overnight at $4^{\circ} \mathrm{C}$ with the following primary antibodies: rabbit anti- $\beta$-galactosidase (1:3000; 5 Prime $\rightarrow 3$ Prime, Boulder, CO), rabbit anti-synatoporin (1:6000; Synaptic Systems, Gottingen, Germany), mouse anti-mitogen-activated protein-2 (MAP2) (1:10,000; Sigma, St. Louis, MO), and mouse anti-synapsin1 (1:3000; Synaptic Systems). Sections were washed several times in TBS and incubated for $1 \mathrm{~h}$ with biotinylated goat anti-mouse IgG or biotinylated goat anti-rabbit IgG (1:1000; Jackson ImmunoResearch, West Grove, PA) or incubated overnight with Alexa Fluor 488-conjugated goat anti-mouse IgG and Alexa Fluor 594-conjugated goat anti-rabbit IgG (1:8000; Invitrogen, Carlsbad, CA) for double-labeling experiments. Labeled sections were visualized on either a Zeiss (Jena, Germany) Axioplan II or a Zeiss laser scanning confocal (LSM510) microscope.

Membrane preparation and protein gels. Hippocampi were isolated from adult mice and homogenized in $0.3 \mathrm{~m}$ sucrose. The homogenized tissue was centrifuged at $900 \times \mathrm{g}$ for $10 \mathrm{~min}$ at $4^{\circ} \mathrm{C}$. The supernatant containing the small synaptosomes were collected, and the pellet was resuspended in sucrose and centrifuged again at $900 \times \mathrm{g}$ for an additional $10 \mathrm{~min}$ at $4^{\circ} \mathrm{C}$. The pooled supernatants were then centrifuged at $17,000 \times g$ for $55 \mathrm{~min}$ at $4^{\circ} \mathrm{C}$. This yields a pellet that is enriched with small hippocampal synaptosomes (P2). The large mossy fiber synaptosomes sedimented with the nuclei after the initial low-speed spin. This pellet was then suspended in $1.5 \mathrm{ml}$ of $18 \%$ Ficoll in $0.3 \mathrm{M}$ sucrose and centrifuged at $7500 \times g$ for $40 \mathrm{~min}$. The supernatant from this spin was collected, diluted in $4 \mathrm{vol}$ of $0.3 \mathrm{M}$ sucrose, and spun again at 13,000 $\times g$ for $20 \mathrm{~min}$ at $4^{\circ} \mathrm{C}$. This spin yields a final $\mathrm{P} 3$ pellet containing the large mossy fiber synaptosomes.

Protein isolated from the whole hippocampus $(\mathrm{H})$, small hippocampal synaptosomes (P2), and large mossy fiber synaptosomes (P3) was diluted in loading buffer (50 mm Tris-Cl, $100 \mathrm{~mm}$ DTT, 2\% SDS, 0.1\% bromophenol blue, and $10 \%$ glycerol) and run on a $10 \%$ polyacrylamide gel. Gels were transferred to Immobilon-P membrane (Millipore, Bedford, MA), blocked in 0.1 м PBS containing 3\% IgG-free BSA (Jackson ImmunoResearch), $0.4 \%$ NP-40, $0.2 \%$ Tween 20 , and $10 \%$ normal goat serum, and blotted overnight with the following antibodies: rabbit anti- $\beta$ galactosidase (1:10,000; 5 Prime $\rightarrow 3$ Prime), mouse anti- $\beta$-actin (1: 30,000; Sigma), rabbit anti-synatoporin (1:30,000; Synaptic Systems), and mouse anti-postsynaptic density 95 (PSD95) (1:160,000; Upstate Biotechnology, Lake Placid, NY). Blots were incubated with peroxidaseconjugated goat anti-mouse or anti-rabbit secondary antibodies $(1: 10,000)$ and visualized with enhanced chemiluminescence (LumiLight $^{\text {plus; }}$ Roche Diagnostics, Indianapolis, IN). 


\section{Results}

\section{Ephrin-B3 is expressed at high levels in mossy fiber axons} and terminals

Previous in situ hybridization studies have demonstrated that mRNA coding for ephrin-B3 is expressed at high levels in the hippocampal granule neurons in the dentate gyrus and that ephrin-B1 and ephrin-B2 are expressed at significantly lower levels in this region (Grunwald et al., 2001; Liebl et al., 2003). More direct localization of B-ephrins has been hampered by the lack of selective antibodies for the individual B-ephrin proteins. However, the development of mice engineered to express mutant-tagged protein allowed us to directly determine the localization of the ephrin-B3- $\beta$-galactosidase fusion protein in ephrin-B3 ${ }^{\text {lacZ/lacZ }}$ mutant mice (Yokoyama et al., 2001). This ephrin-B3 fusion protein is efficiently inserted into the membrane and shows an expression pattern consistent with that predicted by mRNA localization in embryonic mice (Gale et al., 1996; Bergemann et al., 1998; Yokoyama et al., 2001). To localize ephrin-B3 protein in adult mice, we first performed X-gal histochemistry on sections from ephrin-B3 ${ }^{\text {lacZ/lacZ }}$ mice. We observed the distinctive blue coloration that results from $\beta$-galactosidase hydrolysis of X-gal in specific and anatomically distinct regions of the brain, including the subiculum, fimbria/fornix, lateral septum, inferior colliculus, and the dopaminergic medial forebrain bundle in which the midbrain dopaminergic fibers project and innervate the striatum (Fig. 1a). In the hippocampus, there was very distinct staining in the dentate hilus and the stratum lucidum region through which the main mossy fiber axon bundle passages. There was also intense staining in the subiculum, the output of the CA1 region. To further localize ephrin-B3- $\beta$ galactosidase protein, we performed immunohistochemical analysis of slices from ephrin-B3 ${ }^{\text {lacz/lacz }}$ mice using anti- $\beta$ galactosidase antibody. In coronal hippocampal slices, we observed distinct staining in the stratum lucidum and infrapyramidal layer, the termination zones of the mossy fibers, suggesting that ephrin-B3 is localized to the mossy fiber axons and terminals (Fig. 1c,d). In addition, we homogenized hippocampal tissue from ephrin-B3 ${ }^{\text {lacZ/lacz }}$ mice and isolated the synaptosome fractions (P3), which have been demonstrated previously to be enriched in mossy fiber boutons (Terrian et al., 1988). Immunoblot analysis of the P3 fraction confirmed that ephrin-B3 is localized to mossy fiber terminals along with the presynaptic protein synaptoporin, whereas no anti- $\beta$-galactosidase signal was evident in the P2 fraction in which we localized the postsynaptic marker PSD95 (Fig. 1b). Finally immunohistochemical experiments were performed using fluorescent-labeled secondary antibodies to determine whether $\beta$-galactosidase immunoreactivity could be colocalized with presynaptic or postsynaptic markers in the stratum lucidum area of CA3. Little or no colocalization was found between anti- $\beta$-galactosidase immunoreactivity and the postsynaptic dendritic marker MAP2 (Fig. 1e,f). However, most of the large putative mossy fiber terminals in the confocal plane contained both $\beta$-galactosidase immunoreactivity (red) and synapsin I immunoreactivity (green) (Fig. $1 g$, $h$, see arrows in $h$; colocalization appears yellow).

Eph receptors and ephrin ligands are critical to several developmental processes, including axon pathfinding and cell migration (Kullander and Klein, 2002). Therefore, it was important to confirm that both pyramidal cells layers and mossy fiber inputs were not grossly altered in ephrin-B3 mutants. To determine whether the mossy fiber axons were disrupted in ephrin-B3 mutant mice, we stained sections with an antibody against the pre-

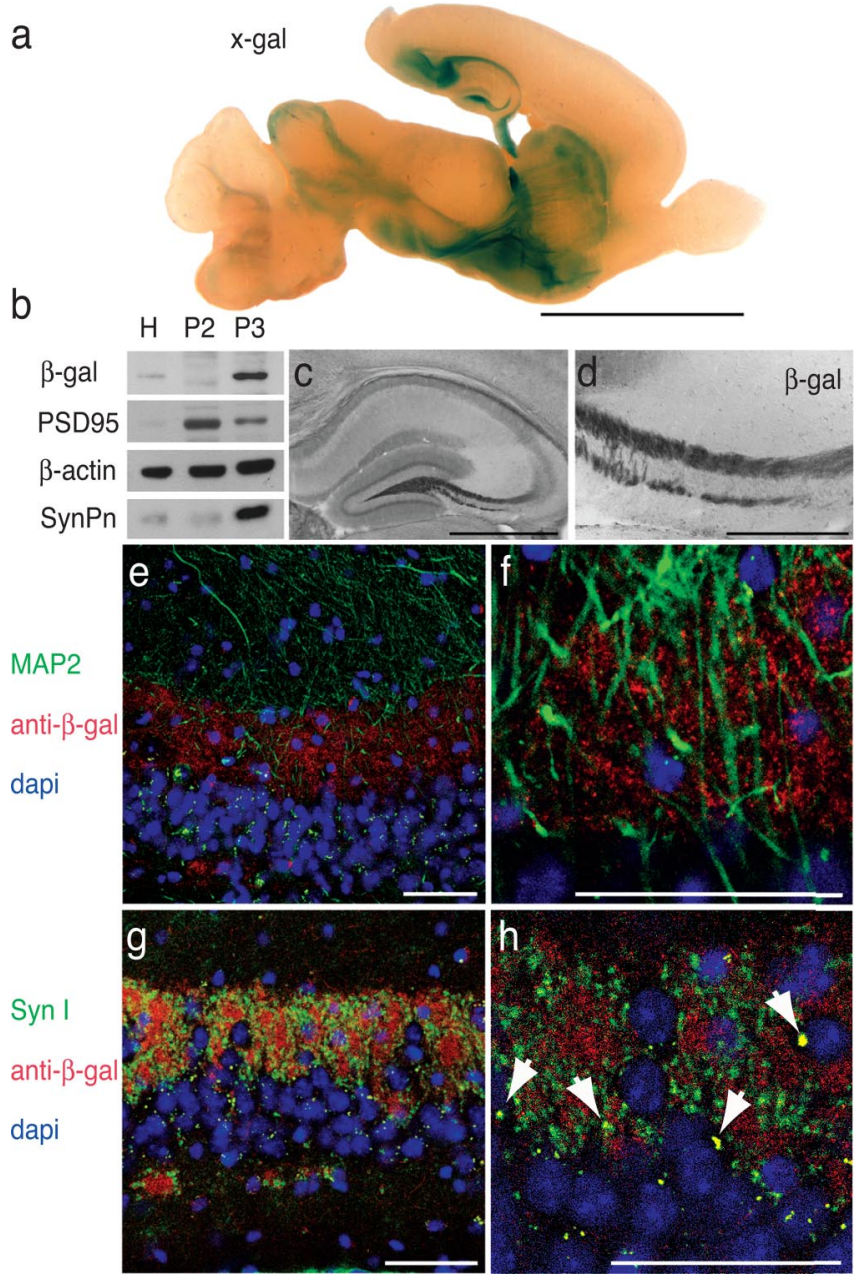

Figure 1. Ephrin-B3 is localized to mossy fiber axons and synaptic terminals. $\boldsymbol{a}$, Parasagittal section from ephrin-B $3^{\text {lacZ/lacZ }}$ mice stained with X-gal. In the hippocampus, X-gal reaction product was observed throughout the mossy fiber termination zones in the dentate hilus and stratum lucidum of CA3. Additional reaction product was clearly apparent in the striatum and in discrete fiber bundles in the ventral midbrain and inferior colliculus. Scale bar, $5 \mathrm{~mm}$. $\boldsymbol{b}$, Western blot analysis of hippocampal protein from ephrin-B3 lacz/lacz mice. A single membrane containing protein isolated from total hippocampus $(\mathrm{H})$, small synaptosomes (P2), and large mossy fiber synaptosomes (P3) was blotted with antibodies raised against $\beta$-galactosidase to confirm the presence of the ephrin-B3- $\beta$-galactosidase fusion protein in mossy fiber synapses. Additional blotting was performed with antibodies raised against PSD95, $\beta$-actin, or synaptoporin (SynPn) to confirm that the P3 fraction contained mossy fiber synapses. $\boldsymbol{c}, \boldsymbol{d}$, Anti- $\beta$ galactosidase immunoreactivity in hippocampal sections taken from ephrin-B $3^{\text {lacz/lacz }}$ mice further confirm that the ephrin-B3- $\beta$-galactosidase fusion protein was present in mossy fiber termination zones in the dentate hilus and stratum lucidum of CA3. Anti- $\beta$-galactosidase immunoreactivity was also apparent in the infrapyramidal cell region of the CA3. Scale bars: $\boldsymbol{c}, 1$ $\mathrm{mm} ; \boldsymbol{d}, 300 \mu \mathrm{m}$. In stratum lucidum, triple-immunofluorescent labeling and confocal microscopy confirmed that immunoreactivity for ephrin-B3- $\beta$-galactosidase fusion protein (red) was not colocalized with the postsynaptic dendritic marker MAP2 (green) $(\boldsymbol{e}, \boldsymbol{f})$ but was colocalized with the presynaptic marker synapsin I (green) $(\boldsymbol{g}, \boldsymbol{h})$; colocalization appears yellow (see arrows in $\boldsymbol{h}$ ). Scale bars: $\boldsymbol{e}-\boldsymbol{h}, 50 \mu \mathrm{m}$.

synaptic protein synaptoporin, which is abundant in the mossy fiber terminals. In sections from wild-type mice, synaptoporinimmunoreactive mossy fiber terminals were apparent throughout the hilar region and stratum lucidum of CA3 (Fig. 2a). Interestingly, in ephrin-B3 ${ }^{\text {lacz/lacz }}$ mice, we found that there was an abnormally long band of synaptoporin immunoreactivity in the infrapyramidal region (Fig. $2 d-f$ ), suggesting that this normally minor projection to the CA3 pyramidal neurons might be increased with this mutation. Analysis of the relative length of the 

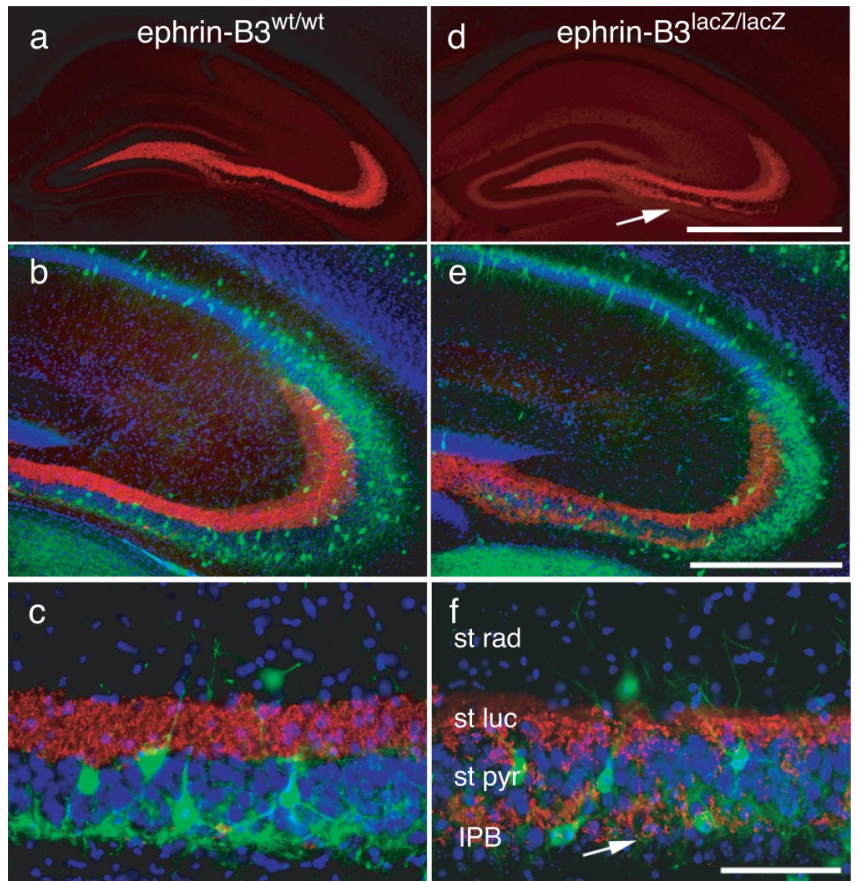

Figure 2. Immunohistological analysis of hippocampi from ephrin-B3 ${ }^{\text {lacz/lacz }}$ mice. $\boldsymbol{a}, \boldsymbol{d}$, Hippocampal sections from wild-type and ephrin-B $3{ }^{\text {lacz/lacz }}$ mice stained with presynaptic marker synaptoporin (red) to highlight the mossy fiber bundle. $\boldsymbol{b}, \boldsymbol{e}$, Triple staining with synaptoporin, DAPI (blue) to highlight cell body layers, and parvalbumin (green) to highlight a subpopulation of interneurons. $\boldsymbol{c}, \boldsymbol{f}$, Higher magnification of the CA3 region in wild-type and ephrin-B3 ${ }^{\text {lacz/lacz }}$ mice. No gross morphological disturbances in the main mossy fiber bundle

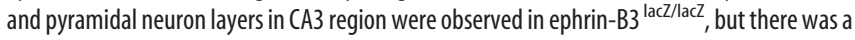
significant increase in the extent of the infrapyramidal blade of the mossy fiber projection. st rad, Stratum radiatum; st luc, stratum lucidum; st pyr, stratum pyramidale. Scale bars: $\boldsymbol{a}, \boldsymbol{d}, 1$ $\mathrm{mm} ; \boldsymbol{b}, \boldsymbol{e}, 500 \mu \mathrm{m} ; \boldsymbol{c}, \boldsymbol{f}, 100 \mu \mathrm{m}$.

infrapyramidal blade (IPB) to the suprapyramidal blade revealed a statistically significant increase in the relative length of the IPB in ephrin-B3 ${ }^{\text {lacZ/lacZ }}$ mice (ephrin-B3 ${ }^{\text {lacZ/lacZ }}, 0.47 \pm 0.07$; ephrin-B3 $\left.^{\mathrm{wt} / \mathrm{wt}}, 0.24 \pm 0.05 ; p<0.05\right)$. In contrast to the disruption in IPB length, there was no alteration in the length of the suprapyramidal mossy fiber projection in stratum lucidum of ephrin-B3 ${ }^{\text {lacZ/lacZ }}$ mice. Furthermore, triple labeling of hippocampal sections with the nuclear stain $4^{\prime}, 6^{\prime}$-diamidino-2phenylindole (DAPI), synaptoporin, and the inhibitory basket cell marker parvalbumin did not reveal any differences in the lamination of the hippocampal pyramidal cell layer or the relative density of inhibitory interneurons and parvalbumin immunoreactivity axonal plexus in the CA3 region of ephrin-B3 ${ }^{\text {lacZ/lacZ }}$ mice compared with controls (Fig. 2).

\section{Mossy fiber LTP is impaired in ephrin-B3 mutant mice}

To test for the involvement of ephrin-B3 in mossy fiber synaptic plasticity, we made whole-cell patch-clamp recordings from pyramidal neurons in the CA3 region of the hippocampus from both strains of ephrin-B3 mice and their wild-type and heterozygote littermates. We first tested mossy fiber LTP in ephrinB ${ }^{\text {lacZ/lacZ }}$ mice using a standard $1 \mathrm{~s}, 100 \mathrm{~Hz}$ stimulation induction protocol repeated three times. We found that mossy fiber LTP was significantly impaired in the homozygote ephrin-B3 ${ }^{\text {lacZ/lacZ }}$ mice compared with wild-type littermate controls (Fig. 3a,b). Twenty to $30 \mathrm{~min}$ after a tetanic induction protocol, mossy fiber EPSCs were potentiated $207 \pm 18.0 \%(n=8)$ in slices from ephrin$\mathrm{B} 3^{\mathrm{wt} / \mathrm{wt}}$ mice, whereas in slices from ephrin-B3 ${ }^{\text {lacZ/lac }}$ mice, EPSCs

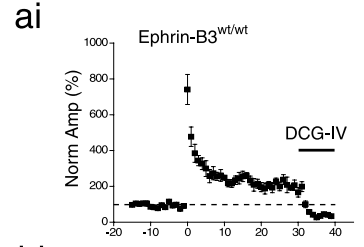

bi

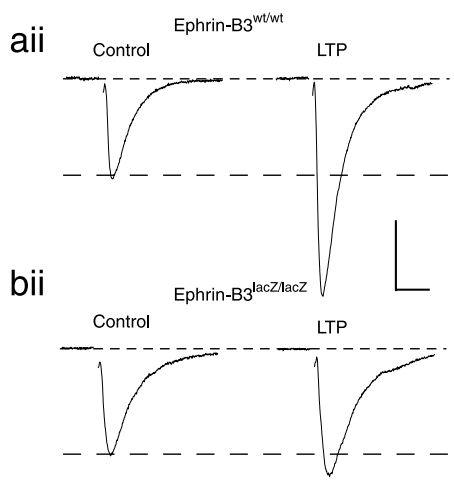

ci
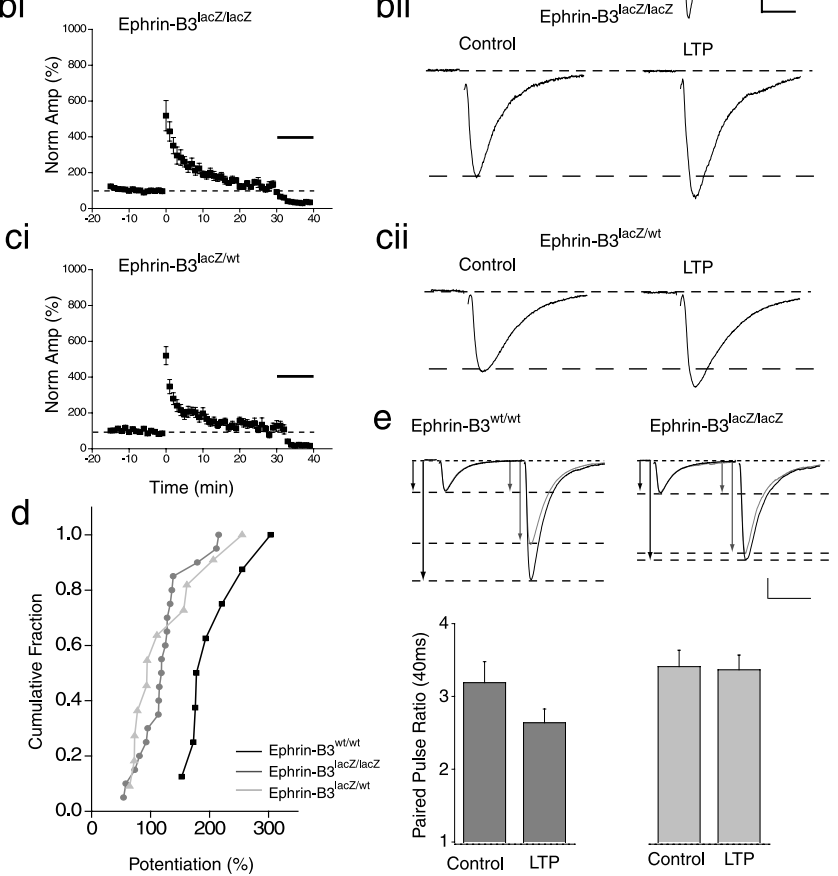

Figure 3. Mossy fiber LTP is disrupted in ephrin-B3 ${ }^{\text {lacz/lacz }}$ mice. ai, Averaged time course of mossy fiber LTP for all recordings from ephrin-B3 ${ }^{\text {wt/wt }}$ mice. Magnitude of LTP was calculated as the percentage increase in the size of the mossy fiber EPSC 20-30 min after the tetanus compared with $15 \mathrm{~min}$ control period before induction. Black bar represents application of group II mGluR agonist at the end of each experiment. aii, Representative EPSC traces from one experiment in ephrin-B3 ${ }^{\text {wt/wt }}$ mice before and after the induction of LTP Calibration: $10 \mathrm{~ms}, 200 \mathrm{pA}$. bi, Averaged time course of mossy fiber LTP in ephrin-B3 lacz/lacz mice. bii, Representative EPSC traces from one experiment during control and $20-30 \mathrm{~min}$ after tetanic stimulation. ci, cii, Averaged time course of mossy fiber LTP and representative EPSC traces from ephrin-B 3 lacz/wt $^{\text {lat }}$ mice. $\boldsymbol{d}$, Cumulative probability distribution of mossy fiber LTP measured as the percentage potentiation 25-30 min after tetanus compared with control period. LTP in ephrin-B3 laczllacZ and heterozygous littermates was significantly lower than in wild-type littermate controls. $\boldsymbol{e}$, Paired-pulse ratio measured at an interstimulus interval of $40 \mathrm{~ms}$ is reduced after LTP in wildtype mice signifying an increase in release probability of the synapse. Top panel shows representative traces from ephrin-B3 ${ }^{\text {wt/wt }}$ and ephrin-B $3^{\text {lacz/lacz }}$ before and after LTP. The traces are scaled to the first EPSC in the pair to highlight the paired-pulse ratio. Calibration: $50 \mathrm{~ms}, 200 \mathrm{pA}$; $50 \mathrm{~ms}, 510 \mathrm{pA}$ for ephrin-B3 ${ }^{\text {wt/wt }}$ after LTP. Bottom panel summarized paired-pulse data for all recordings. A significant change in paired-pulse ratio is observed after LTP in ephrin-B3 ${ }^{\text {wt/wt }}$ mice but no change in recordings from ephrin-B $33^{\text {lacz/lacz }}$ mice.

showed little potentiation at this time point (122 $\pm 9.4 \% ; n=20$; $p<0.001$ compared with wild type). Similarly, mossy fiber LTP from heterozygote ephrin-B3 ${ }^{\text {lacZ/wt }}$ mice was also significantly impaired $(124 \pm 19 \% ; n=11 ; p<0.05)$ (Fig. $3 c, d)$. In experiments from all three genotypes, there was no significant difference in the degree of inhibition by a group II mGluR agonist (DCG-IV, $1 \mu \mathrm{M}$ ) (ephrin-B3 $^{\mathrm{wt} / \mathrm{wt}}, 82 \pm 3.0 \%$; ephrin-B3 ${ }^{\text {lacZ/wt }}, 84 \pm 2.1 \%$; $p>0.05$; ephrin-B3 $3^{\text {lacZ/lacZ }}, 77 \pm 2.0 \% ; p>0.05$ percentage block of the EPSC by DCG-IV). This, in combination with our other criteria for determining monosynaptic mossy fiber stimulation (see Materials and Methods), demonstrate that we did not have substantial contamination by activation of collateral fibers in any of these recordings. In recordings from wild-type mice, paired-pulse facilitation measured 
a

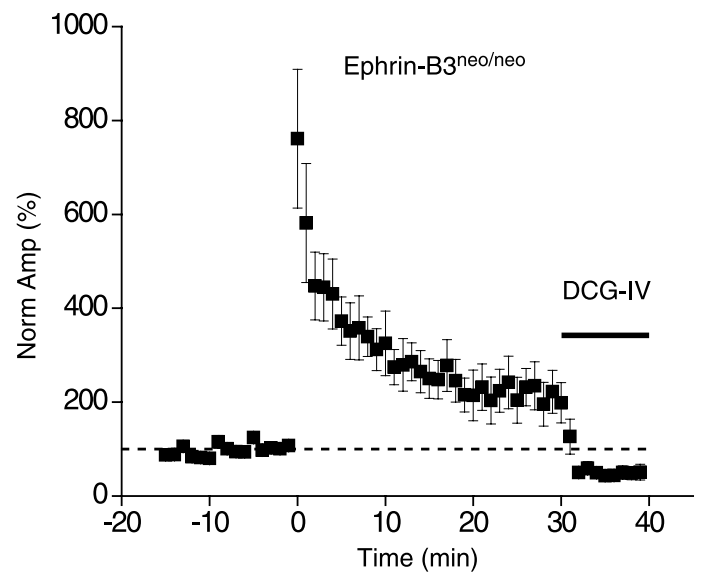

b

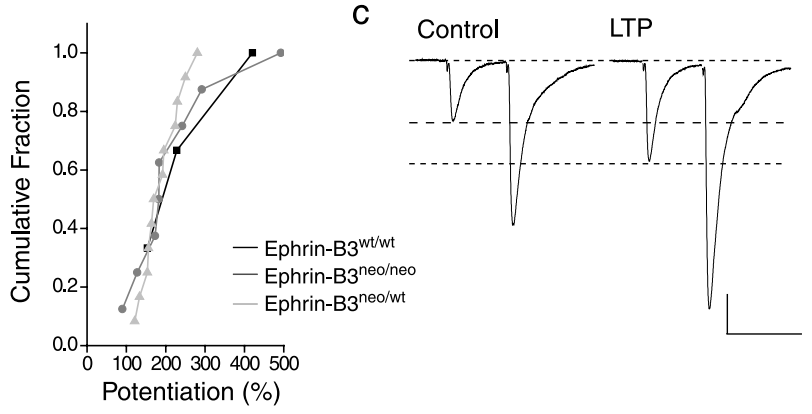

Figure 4. Magnitude of mossy fiber LTP is not altered in ephrin-B $3^{\text {neo/neo }}$ hypomorphic null mice. $\boldsymbol{a}$, Time course of LTP in ephrin-B ${ }^{\text {neo/neo }}$ mice averaged for all recordings. $\boldsymbol{b}$, Cumulative probability histogram for mossy fiber LTP recordings from ephrin-B3 ${ }^{\text {neo/neo }}$ mice and heterozygote and wild-type littermates. Magnitude of LTP measured 20-30 min after tetanus is not significantly different between the three genotypes. c, Representative EPSC traces from ephrin$\mathrm{B} 3^{\text {neo/neo }}$ before and after induction of mossy fiber LTP. Calibration: $50 \mathrm{~ms}, 200 \mathrm{pA}$.

at an interstimulus interval of $40 \mathrm{~ms}$ showed a significant decrease after LTP induction, consistent with an increase in release probability of the potentiated synapses (control, $3.2 \pm 0.3$; LTP, $2.6 \pm 0.2$; $n=8 ; p<0.05$ ) (Fig. 3e). In recordings from ephrin-B3 ${ }^{\text {lacZ/lacZ }}$ mice, there was no significant change in this parameter between 20 and 30 min after tetanic stimulation (control, $3.2 \pm 0.3$; LTP, $3.2 \pm 0.3 ; n=$ $19 ; p>0.05)$. Potentiation immediately after tetanus [posttetanic potentiation (PTP)] was also significantly reduced in both ephrinB $3^{\text {lacZ/lacZ }}$ and ephrin-B3 ${ }^{\text {lacZ/wt }}$ mice (ephrin-B3 ${ }^{\text {wt/wt }}, 740 \pm 84 \%$, $n=8$; ephrin-B3 ${ }^{\text {lacZ/lacZ }}, 520 \pm 82 \%, n=20$; ephrin-B3 ${ }^{\text {lacZ/wt }}$, $520 \pm 51 \%, n=11 ; p<0.05)$. Thus, mossy fiber LTP and PTP are both impaired in ephrin-B3 ${ }^{\text {lacZ/lacZ }}$ and ephrin-B3 ${ }^{\text {lacZ/wt }}$ mice, supporting a central role for B-ephrins in mossy fiber plasticity.

To determine whether this impairment in mossy fiber plasticity was apparent when ephrin-B3 is ablated, we made recordings from the hypomorphic null ephrin-B3 ${ }^{\text {neo/neo }}$ mice. Mossy fiber potentiation induced by a tetanus was $270 \pm 80 \%(n=3)$ in wild-type littermates, which is not significantly different from the potentiation seen in slices from ephrin-B3 ${ }^{\text {neo/neo }}$ homozygote $(200 \pm 44 \% ; n=9 ; p>0.05)$ (Fig. 4) and ephrin-B3 ${ }^{\text {neo/wt }}$ heterozygote $(190 \pm 20 \% ; n=7 ; p>0.05)$ mice (Fig. $4 b)$. These data support the hypothesis that redundancy through multiple presynaptic B-ephrins can compensate for the ablation of ephrin-B3, whereas the presence of the ephrin-B3- $\beta$-galactosidase protein in mossy fiber terminals would act as a dominant negative to B-ephrin reverse signaling, thus blocking mossy fiber LTP.
Short-term plasticity is normal in ephrin-B3 mutant mice Mossy fiber synaptic transmission displays very robust and characteristic short-term plasticity. Repeated activation of mossy fiber synapses causes a large and reversible increase in release probability attributable to increases in residual calcium levels in the presynaptic terminals (Zucker and Regehr, 2002). To test whether this is a possible reason for the impairment in mossy fiber LTP in ephrin-B3 $3^{\text {lacZ/lacZ }}$ mice, we investigated two forms of short-term plasticity in mossy fibers. Pairs of stimuli were delivered to mossy fiber afferents separated by a variable interstimulus interval. The second EPSC evoked by this pair of stimuli was enhanced compared with the first EPSC. We calculated pairedpulse ratios as the ratio of the peak of the second EPSC to the first EPSC $\left(\right.$ EPSC $_{2} /$ EPSC $_{1}$ ) at several interstimulus intervals between 40 and $500 \mathrm{~ms}$ in ephrin-B3 ${ }^{\text {lacZ/lacZ }}$ mice and their wild-type and heterozygote littermates. Paired-pulse ratios were found not to be significantly different between mice in each of the genotype groups (Fig. 5a). At $40 \mathrm{~ms}$ interval, paired-pulse ratios for mossy fiber EPSC in slices from ephrin-B3 ${ }^{\text {lacZ/lacZ }}$ and ephrin-B3 ${ }^{\text {wt/wt }}$ were $3.4 \pm 0.2[n=9(\mathrm{wt} / \mathrm{wt})]$ and $3.5 \pm 0.3[n=17(\mathrm{lacZ} / \mathrm{lacZ})]$. The ratios were as follows: at $80 \mathrm{~ms}$, wt/wt, $3.3 \pm 0.2, n=9$; lacZ/lacZ, $3.1 \pm 0.2, n=13$; at $120 \mathrm{~ms}$, wt/wt, $2.9 \pm 0.1, n=9$; lacZ/lacZ, $2.8 \pm 0.2, n=13$; at $160 \mathrm{~ms}$, wt/wt, $3.0 \pm 0.2, n=9$; lacZ/lacZ, $3.0 \pm 0.2, n=12$; at $200 \mathrm{~ms}$, wt/wt, $2.8 \pm 0.1, n=12$; lacZ/lacZ, $2.9 \pm 0.3, n=12$; at $300 \mathrm{~ms}$, wt/wt, $2.4 \pm 0.1, n=9$; lacZ/lacZ, $2.1 \pm 0.1, n=8$; at $500 \mathrm{~ms}$, wt/wt, $2.2 \pm 0.2, n=9$; lacZ/lacZ, $2.0 \pm 0.1, n=10$.

We also measured frequency facilitation of mossy fiber EPSCs at three stimulation frequencies. Mossy fiber EPSCs were potentiated by $160 \pm 9.1 \%(n=5)$ in ephrin-B $3^{\mathrm{wt} / \mathrm{wt}}$ and by $170 \pm 22 \%$ $(n=4)$ in ephrin-B3 $3^{\text {lacZ/lacZ }}$ mice $(p>0.05)$ when stimulation frequencies were increased to $0.2 \mathrm{~Hz}$ for $2 \mathrm{~min}$ from a basal stimulation frequency of $0.05 \mathrm{~Hz}$ (Fig. $5 b, c$ ). Similarly there was no difference in this form of short-term plasticity at $0.5 \mathrm{~Hz}$ (ephrin$\mathrm{B} 3^{\mathrm{wt} / \mathrm{wt}}, 330 \pm 44 \%, n=5$; ephrin-B3 ${ }^{\text {lacZ/lacZ }}, 350 \pm 60 \%, n=4$; $p>0.05$ ) or $1 \mathrm{~Hz}$ stimulation (ephrin-B $3^{\mathrm{wt} / \mathrm{wt}}, 510 \pm 58 \%, n=5$; ephrin-B3 $\left.^{\text {lacZ/lacZ }}, 540 \pm 100 \%, n=4 ; p>0.05\right)$. These data suggest that there is no general impairment in the ability of the mossy fiber synapse to facilitate and that the impairment in the induction and or expression of mossy fiber LTP is a specific consequence of the loss of ephrin reverse signaling.

\section{NMDA receptor-dependent $\mathrm{LTP}$ in the CA1 region is normal in ephrin-B3 mutant mice}

The best characterized form of LTP is that expressed at the Schaffer collateral to CA1 synapse in the hippocampus. We next examined this form of NMDA receptor-dependent LTP to determine whether other forms of synaptic plasticity are impaired in these mice and also because a previous study had found that CA1 LTP is impaired in ephrin-B2 and ephrin-B3 knock-out mice (Grunwald et al., 2004). We performed field potential recording experiments in the CA1 region in slices from both ephrin-B3 $3^{\text {lacZ/lacZ }}$ and ephrin-B3 ${ }^{\text {neo/neo }}$ while stimulating the Schaffer collateral inputs. We found that the magnitude of potentiation of the slope of the field EPSP (fEPSP) 30-40 min after theta burst stimulation was identical in ephrin$\mathrm{B}^{\mathrm{wt} / \mathrm{wt}}(160 \pm 9.3 \%$; $n=8)$, ephrin-B3 ${ }^{\text {neo/neo }}(170 \pm 7.0 \%, n=4$; $p>0.05)$, and ephrin-B3 ${ }^{\text {lacZ/lacZ }}(150 \pm 6.3 \% ; n=10 ; p>0.05)$ mice (Fig. 6).

\section{Mossy fiber synapses can undergo normal potentiation in ephrin-B3 mutant mice}

Mossy fiber synaptic transmission is potentiated by forskolin, which is thought to act by increasing cAMP and subsequent ac- 

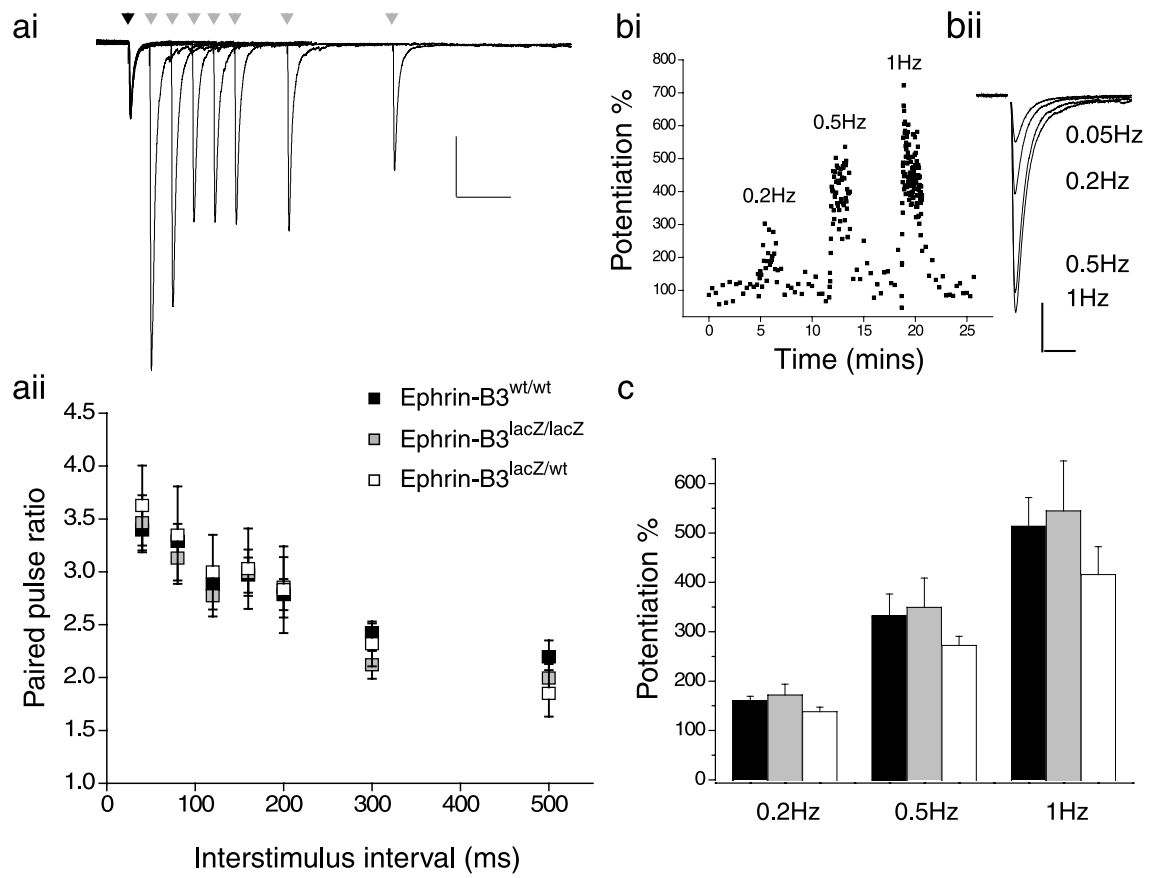

C

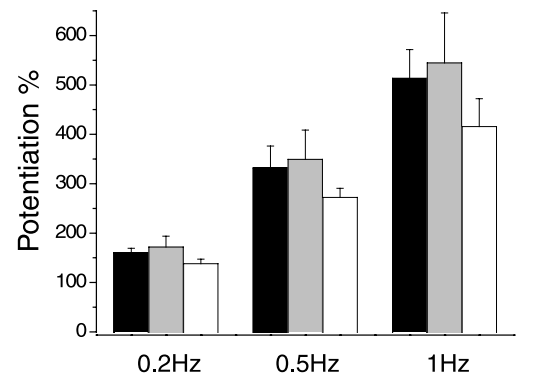

Figure 5. Short-term mossy fiber synaptic plasticity is not impaired in ephrin-B $3{ }^{\text {lacz/lacz }}$ mice. ai, Representative mossy fiber EPSCs evoked using paired-pulse protocols at several interstimulus intervals in ephrin-B3 ${ }^{\text {lacz/lacz }}$ mice. Calibration: $100 \mathrm{~ms}, 200$ pA. aii, Paired-pulse ratios calculated as EPSC $/$ EPSC $_{1}$ for a range of interstimulus intervals for ephrin-B3 lacz/lacZ and wild-type and heterozygous littermates. There was no significant difference observed at any of the intervals tested ( $40-500 \mathrm{~ms}$ ) in recordings from any of the genotypes. $\boldsymbol{b}$, Time course of frequency facilitation from one ephrin- $B 3^{\text {lacz/lacz }}$ recording. Frequency of afferent stimulation was increased from 0.05 to $0.2,0.5$, and $1 \mathrm{~Hz}$ without a change in stimulation intensity. bii, Representative EPSC traces at each stimulation frequency. Calibration: $20 \mathrm{~ms}, 200 \mathrm{pA}$. c, Summary of frequency facilitation at the three stimulation frequencies for ephrin-B3 ${ }^{\text {wt/wt }}$ (black), ephrin-B3 lacz/lacz (gray), and ephrin-B3 lacz/wt (white) mice.

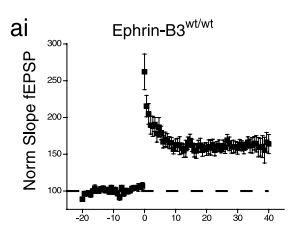

aii $\quad$ Ephrin-B3 ${ }^{\text {lacZ/acz }}$
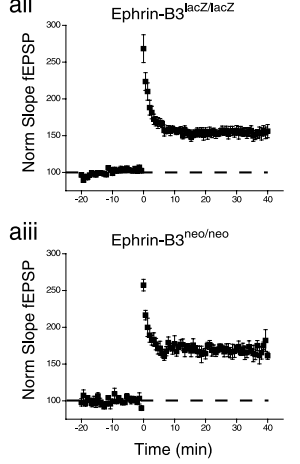

b
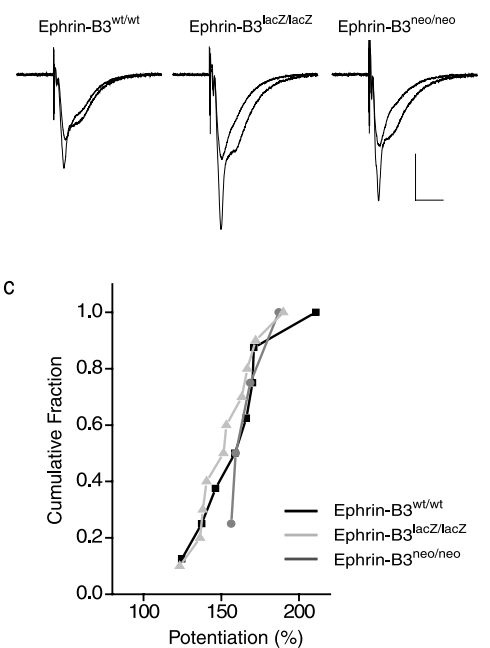

Figure 6. Magnitude of NMDA receptor-mediated LTP at the Schaffer collateral to CA1 pyramidal neuron synapse induced by theta burst stimulation is normal in ephrin-B3 mutant mice. ai-aiii, Time course of CA1 LTP in ephrin-B3 mutant and wild-type mice. Control wild-type littermate recordings from both groups showed no significant difference in the magnitude of LTP and were therefore grouped together. $\boldsymbol{b}$, Representative CA1 fEPSPs before and after the

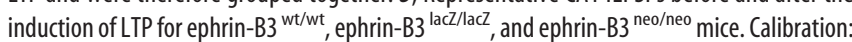
$20 \mathrm{~ms}, 0.4 \mathrm{mV}$. c, Cumulative distribution histogram of CA1 LTP from ephrin-B3 mutants.

tivation of protein kinase A (PKA) in the presynaptic mossy fiber terminal (Weisskopf et al., 1994). To test whether forskolin can bypass the requirement for ephrin-B3 signaling in potentiating mossy fiber synapses, we tested the effects of forskolin in ephrin-
B3 $3^{\text {lacZ/lacZ }}$ mice. In wild-type littermates, mossy fiber EPSCs were potentiated by $220 \pm 70 \%(n=3)$ at $20-30 \mathrm{~min}$ after washout of a $20 \mathrm{~min}$ application of forskolin. Forskolin also enhanced mossy fiber EPSCs in ephrin-B3 ${ }^{\text {lacZ/lacZ }}$ mice to $290 \pm$ $46 \%(n=6)$, a value not significantly different from wild-type recordings $(p>$ 0.05 ) (Fig. $7 a, b)$. In both groups, pairedpulse ratios measured at $40 \mathrm{~ms}$ intervals were depressed after forskolin-mediated potentiation, in accord with an increase in release probability of the synapse. Therefore, mossy fiber synaptic transmission can be potentiated normally in ephrinB3 ${ }^{\text {lacZ/lacZ }}$ mice by activation of PKA, suggesting that activation of this enzyme is downstream of ephrin reverse signaling.

\section{Discussion}

In this study, we demonstrate that B-ephrin-mediated reverse signaling is a critical requirement for LTP at mossy fiber synapses. We have examined mossy fiber synaptic plasticity in mutant mice in which the ephrin-B3 locus has been targeted to produce mice that are hypomorphic null to eliminate forward and reverse signaling or express an ephrin-B3- $\beta$-galactosidase fusion protein that is unable to transduce cell-autonomous reverse signals. We made several interesting observations that have furthered our knowledge of B-ephrins in this form of synaptic plasticity. First, using the ephrin-B $3^{\text {lacZ/lac } Z}$ mice, we were able to confirm for the first time that ephrin-B3 protein is expressed at high levels in the mossy fiber axons and terminals. Second, there did not appear to be any gross alterations in hippocampal architecture in ephrin-B3 mutant mice, in agreement with previous findings (Grunwald et al., 2004). Finally, we found that B-ephrin reverse signaling is required for mossy fiber LTP, because this form of synaptic plasticity is specifically impaired in ephrin-B3 ${ }^{\text {lacz/lacz }}$ mice. Interestingly, we observed that a normal magnitude of mossy fiber LTP could be induced in a hypomorphic ephrin-B3 null mouse.

All three B-ephrins are expressed in the hippocampus, but ephrin-B3 shows the most prominent expression particularly in the dentate gyrus. Therefore, the use of ephrin-B $3^{\text {lacZ/lac } Z}$ mice for studying B-ephrin function in the hippocampus has allowed us to circumvent the requirement for ablation of multiple B-ephrin types. Our data suggest that the presence of a signaling mutant, in which the cytoplasmic domain of ephrin-B3 has been replaced by a lacZ cassette, confers a dominant block to ephrin reverse signaling and thereby impairs mossy fiber LTP. This proposal is supported by the finding that LTP in ephrin-B3 ${ }^{\text {lacZ/wt }}$ heterozygous mice was also disrupted, suggesting that the dominant-negative effect of this fusion protein is apparent when wild-type ephrin-B3 is also expressed in the mossy fiber terminals. Ablation of ephrin-B3 does not have the same effect as the signaling-incompetent ephrin-B3 fusion protein, because mossy fiber LTP is not disrupted in ephrin-B3 ${ }^{\text {neo/neo }}$ mice (for a diagram of the proposed model, see Fig. 7c). This finding is also consistent with the explanation that multiple B-ephrins are expressed in the granule cells and may functionally compensate for one another. 
a

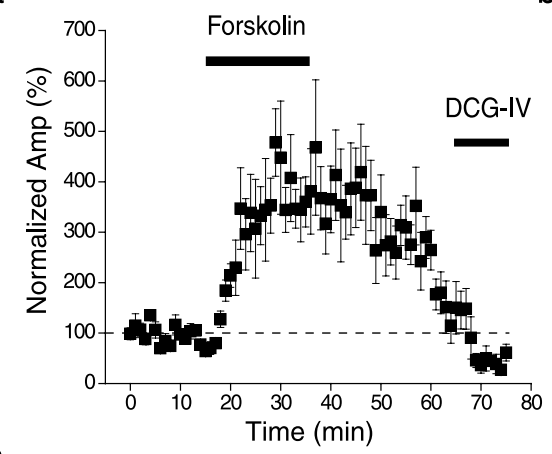

C
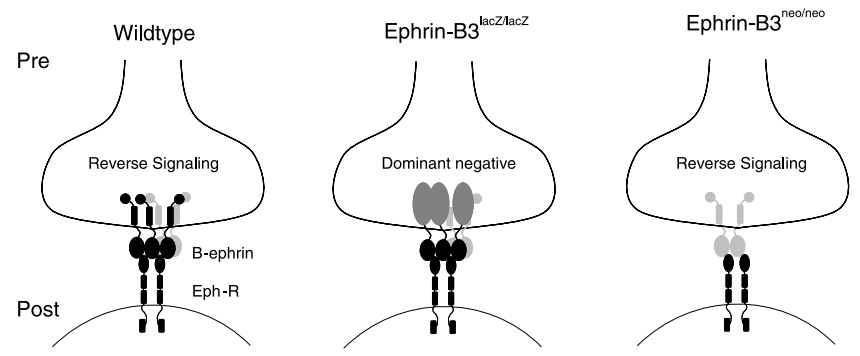

Figure 7. Mossy fiber synapses from ephrin- $B 3^{\text {lacz/lacz }}$ mice can be potentiated normally by forskolin. $\boldsymbol{a}$, Time course of facilitation of mossy fiber synapse by the extracellular application of forskolin to the slice averaged for all recordings from ephrin-B $3{ }^{\text {lacz/lacz }}$ mice. Significant potentiation is observed at $20-30$ min after washout of forskolin, which was not significantly different from that observed in ephrin-B3 ${ }^{\mathrm{wt} / \mathrm{wt}}$ littermates. $\boldsymbol{b}$, Representative EPSC traces before and after forskolin enhancement from ephrin-B3 lacz/lacz recordings. Calibration: $20 \mathrm{~ms}, 200$ pA. C, Diagram representation of ephrin-B reverse signaling at mossy fiber terminals and dominantnegative role of the ephrin-B3- $\beta$-galactosidase fusion protein in ephrin-B ${ }^{\text {lacz/lacZ }}$ mice.

The interpretation of a dominant effect of cytoplasmically disrupted ephrins is consistent with that proposed to explain the phenotype of ephrin-B2 ${ }^{\text {lacZ/wt }}$, which displays hypospadias not found in ephrin-B2 null mutants (Dravis et al., 2004). In addition, biochemical analysis of recombinant ephrin-B2- $\beta$ galactosidase coexpressed in heterologous systems also demonstrated that it acts as a dominant negative to wild-type B-ephrin signaling (Dravis et al., 2004).

The motivation behind these experiments came from previous observations that implicated EphB receptor to B-ephrin signaling as a requirement for mossy fiber LTP (Contractor et al., 2002). In this previous study, we found that disrupting interactions between postsynaptic PSD95/Discs large/zona occludens 1 (PDZ) scaffolding proteins and Eph receptors in CA3 pyramidal neurons could disrupt mossy fiber LTP. The involvement of postsynaptic mechanisms in mossy fiber synaptic plasticity have been disputed (Yeckel et al., 1999; Mellor and Nicoll, 2001), but this study clearly supported a mechanism in which postsynaptic proteins play a crucial role. In addition, we had found that application of fc fusion proteins that disrupt EphB to B-ephrin signaling were also able to block stable mossy fiber LTP. From these experiments, we proposed a model in which a trans-synaptic signal was required for mossy fibers to undergo LTP. We extended these initial findings in the present study. Ephrin-B3 mutant mice have enabled us to confirm the importance of EphB receptor-Bephrin signaling in mossy fiber LTP but additionally provided evidence for the significance of ephrin reverse signaling into mossy fiber terminals. This facilitates the pursuit of novel lines of inquiry about the exact presynaptic molecular mechanisms that govern plasticity at mossy fiber terminals. EphB receptor cell non-autonomous interactions with B-ephrins results in the for- mation of multimeric clusters that induce a conformational change in the cytoplasmic portion of the ephrin protein, allowing it to be phosphorylated at several tyrosine residues (Holland et al., 1996). Reverse signaling by activated tyrosine phosphorylated ephrins could potentially be mediated by binding of Src homology 2 domain proteins (Cowan and Henkemeyer, 2001) or PDZ domain proteins (Lu et al., 2001). To develop a clear picture of LTP at mossy fiber synapses, it is crucial to determine what molecules are involved in downstream signaling, and how they relate to presynaptic proteins already implicated in mossy fiber LTP, including the synaptic vesicle-associated protein Rab3A (Castillo et al., 1997) and its binding partner RIM1 $\alpha$ (Castillo et al., 2002).

LTP has been described in many regions of the CNS, and several synapses have been shown to demonstrate NMDA receptor-independent mechanisms (Malenka and Bear, 2004). There is no evidence that ephrin reverse signaling plays a role in mediating LTP at other synapses, but there are several synapses that display a number of parallel mechanisms that may qualify them as potential candidates for examining this question. Among these are synapses formed by the mossy fiber axons with interneurons in both the hilar region and the stratum lucidum. These synapses are morphologically quite distinct from the large bouton synapse onto the CA3 pyramids (Acsady et al., 1998), but studies of synaptic plasticity at hilar interneurons have uncovered a number of analogous mechanisms that might suggest very similar forms of LTP. LTP at granule cell-hilar basket neuron synapses is expressed as an increase in release probability of the presynaptic terminal, but, similar to LTP at the mossy fiber synapse onto principal neurons, it is dependent on increases in postsynaptic calcium (Alle et al., 2001), again raising the necessity for postsynaptic to presynaptic signaling.

In addition to their involvement in trans-synaptic signalingmediated plasticity, there have been several reports implicating Eph receptor tyrosine kinases and ephrin ligands in NMDA receptor-dependent hippocampal synaptic plasticity. In two separate reports, NMDA receptor-dependent LTP in the CA1 region of the hippocampus was shown to be impaired in EphB2 receptor knock-out mice (Grunwald et al., 2001; Henderson et al., 2001), although one report found deficits in early stage LTP (Henderson et al., 2001) and the other found impairments only in late phase, protein synthesis-dependent LTP (Grunwald et al., 2001). EphB receptors have been demonstrated to associate with NMDA receptors (Dalva et al., 2000) and potentiate their activity (Takasu et al., 2002), therefore providing a potential mechanistic link to NMDA receptor-dependent plasticity. In a subsequent study, it was proposed that both the $\mathrm{B}$-ephrin ligands and $\mathrm{EphB}$ receptors were localized on postsynaptic CA1 pyramidal neurons, and impairments were observed in LTP at Schaffer collateral to CA1 synapses in both ephrin-B2 and ephrin-B3 knock-out mice (Grunwald et al., 2004). Because of the lack of a mechanistic model that might underlie these observations and because we did not observe a pronounced expression of ephrin-B3- $\beta$ galactosidase protein in the CA1 region in our initial studies, we also examined CA1 LTP. Contrary to what was reported previously, we observed no difference in the magnitude of CA1 LTP in ephrin-B3 null mice. In addition, CA1 NMDA receptordependent LTP was also of normal magnitude in ephrin-B3 lacZ/lacZ mice. Therefore, the only deficit we were able to find in ephrin-B3 mutant mice was at the mossy fiber synapse. It remains unclear to us why there is a discrepancy between the present results and those reported previously.

Synaptic plasticity is the most likely cellular correlate of memory formation; thus, the molecules and biochemical pathways 
that underlie its induction and expression are of considerable interest. LTP at mossy fiber synapses relies on completely distinct pathways from synapses that express NMDA receptor-dependent forms of plasticity. Thus, the emerging model for mossy fiber LTP involving increases in postsynaptic calcium, trans-synaptic EphB receptor-ephrin-B association, and presynaptic B-ephrin reverse signaling have provided us with insight into a novel biochemical cascade that regulates synaptic function.

\section{References}

Acsady L, Kamondi A, Sik A, Freund T, Buzsaki G (1998) GABAergic cells are the major postsynaptic targets of mossy fibers in the rat hippocampus. J Neurosci 18:3386-3403.

Alle H, Jonas P, Geiger JR (2001) PTP and LTP at a hippocampal mossy fiber-interneuron synapse. Proc Natl Acad Sci USA 98:14708-14713.

Bergemann AD, Zhang L, Chiang MK, Brambilla R, Klein R, Flanagan JG (1998) Ephrin-B3, a ligand for the receptor EphB3, expressed at the midline of the developing neural tube. Oncogene 16:471-480.

Castillo PE, Janz R, Sudhof TC, Tzounopoulos T, Malenka RC, Nicoll RA (1997) Rab3A is essential for mossy fibre long-term potentiation in the hippocampus. Nature 388:590-593.

Castillo PE, Schoch S, Schmitz F, Sudhof TC, Malenka RC (2002) RIM1alpha is required for presynaptic long-term potentiation. Nature 415:327-330.

Contractor A, Swanson G, Heinemann SF (2001) Kainate receptors are involved in short- and long-term plasticity at mossy fiber synapses in the hippocampus. Neuron 29:209-216.

Contractor A, Rogers C, Maron C, Henkemeyer M, Swanson GT, Heinemann SF (2002) Trans-synaptic Eph receptor-ephrin signaling in hippocampal mossy fiber LTP. Science 296:1864-1869.

Cowan CA, Henkemeyer M (2001) The SH2/SH3 adaptor Grb4 transduces B-ephrin reverse signals. Nature 413:174-179.

Cowan CA, Henkemeyer M (2002) Ephrins in reverse, park and drive. Trends Cell Biol 12:339-346.

Dalva MB, Takasu MA, Lin MZ, Shamah SM, Hu L, Gale NW, Greenberg ME (2000) EphB receptors interact with NMDA receptors and regulate excitatory synapse formation. Cell 103:945-956.

Dravis C, Yokoyama N, Chumley MJ, Cowan CA, Silvany RE, Shay J, Baker LA, Henkemeyer M (2004) Bidirectional signaling mediated by ephrin-B2 and EphB2 controls urorectal development. Dev Biol 271:272-290.

Gale NW, Flenniken A, Compton DC, Jenkins N, Copeland NG, Gilbert DJ, Davis S, Wilkinson DG, Yancopoulos GD (1996) Elk-L3, a novel transmembrane ligand for the Eph family of receptor tyrosine kinases, expressed in embryonic floor plate, roof plate and hindbrain segments. Oncogene 13:1343-1352.

Grunwald IC, Korte M, Wolfer D, Wilkinson GA, Unsicker K, Lipp HP, Bonhoeffer T, Klein R (2001) Kinase-independent requirement of EphB2 receptors in hippocampal synaptic plasticity. Neuron 32:1027-1040.

Grunwald IC, Korte M, Adelmann G, Plueck A, Kullander K, Adams RH,
Frotscher M, Bonhoeffer T, Klein R (2004) Hippocampal plasticity requires postsynaptic ephrinBs. Nat Neurosci 7:33-40.

Harris EW, Cotman CW (1986) Long-term potentiation of guinea pig mossy fiber responses is not blocked by $N$-methyl D-aspartate antagonists. Neurosci Lett 70:132-137.

Henderson JT, Georgiou J, Jia Z, Robertson J, Elowe S, Roder JC, Pawson T (2001) The receptor tyrosine kinase EphB2 regulates NMDA-dependent synaptic function. Neuron 32:1041-1056.

Holland SJ, Gale NW, Mbamalu G, Yancopoulos GD, Henkemeyer M, Pawson T (1996) Bidirectional signalling through the EPH-family receptor Nuk and its transmembrane ligands. Nature 383:722-725.

Kamiya H, Shinozaki H, Yamamoto C (1996) Activation of metabotropic glutamate receptor type $2 / 3$ suppresses transmission at rat hippocampal mossy fibre synapses. J Physiol (Lond) 493:447-455.

Kullander K, Klein R (2002) Mechanisms and functions of Eph and ephrin signalling. Nat Rev Mol Cell Biol 3:475-486.

Liebl DJ, Morris CJ, Henkemeyer M, Parada LF (2003) mRNA expression of ephrins and Eph receptor tyrosine kinases in the neonatal and adult mouse central nervous system. J Neurosci Res 71:7-22.

Lu Q, Sun EE, Klein RS, Flanagan JG (2001) Ephrin-B reverse signaling is mediated by a novel PDZ-RGS protein and selectively inhibits G proteincoupled chemoattraction. Cell 105:69-79.

Malenka RC, Bear MF (2004) LTP and LTD: an embarrassment of riches. Neuron 44:5-21.

Mellor J, Nicoll RA (2001) Hippocampal mossy fiber LTP is independent of postsynaptic calcium. Nat Neurosci 4:125-126.

Murai KK, Pasquale EB (2002) Can Eph receptors stimulate the mind? Neuron 33:159-162.

Sloviter RS, Dichter MA, Rachinsky TL, Dean E, Goodman JH, Sollas AL, Martin DL (1996) Basal expression and induction of glutamate decarboxylase and GABA in excitatory granule cells of the rat and monkey hippocampal dentate gyrus. J Comp Neurol 373:593-618.

Takasu MA, Dalva MB, Zigmond RE, Greenberg ME (2002) Modulation of NMDA receptor-dependent calcium influx and gene expression through EphB receptors. Science 295:491-495.

Terrian DM, Johnston D, Claiborne BJ, Ansah-Yiadom R, Strittmatter WJ, Rea MA (1988) Glutamate and dynorphin release from a subcellular fraction enriched in hippocampal mossy fiber synaptosomes. Brain Res Bull 21:343-351.

Weisskopf MG, Nicoll RA (1995) Presynaptic changes during mossy fibre LTP revealed by NMDA receptor- mediated synaptic responses. Nature 376:256-259.

Weisskopf MG, Castillo PE, Zalutsky RA, Nicoll RA (1994) Mediation of hippocampal mossy fiber long-term potentiation by cyclic AMP. Science 265:1878-1882.

Yeckel MF, Kapur A, Johnston D (1999) Multiple forms of LTP in hippocampal CA3 neurons use a common postsynaptic mechanism. Nat Neurosci 2:625-633.

Yokoyama N, Romero MI, Cowan CA, Galvan P, Helmbacher F, Charnay P, Parada LF, Henkemeyer M (2001) Forward signaling mediated by ephrin-B3 prevents contralateral corticospinal axons from recrossing the spinal cord midline. Neuron 29:85-97.

Zucker RS, Regehr WG (2002) Short-term synaptic plasticity. Annu Rev Physiol 64:355-405. 